\title{
COMPARISON OF DIFFERENT METHODS OF MEASURING TREE VOLUMES IN THE MUNICIPALITY OF ANAPU, PARÁ, BRAZIL
}

\author{
Fabio Miranda Leão ${ }^{1}$, Izildinha de Souza Miranda², Graciliano Galdino Alves dos Santos² Fabiano \\ Emmert $^{2}$, Rodrigo Geroni Mendes Nascimento ${ }^{2} *$ \\ ${ }^{1}$ Pará Federal University, Campus Altamira, Altamira, Pará, Brasil - fabioleao@ufpa.br \\ 2 Amazon Rural Federal University, Graduate Program in Forest Science, Belém, Pará, Brasil - *rodrigo.geroni@ufra.edu.br; \\ mirandaizildinha@gmail.com; ggaldino@gmail.com; fabianoemmert@gmail.com
}

Received for publication: 05/09/2018 - Accepted for publication: 23/04/2020

\begin{abstract}
Resumo
Comparação de diferentes práticas de mensuração do volume de árvores no município de Anapu, Pará. O objetivo desta pesquisa foi comparar três práticas de obtenção do volume de árvores individuais utilizadas amplamente como base para ajuste de funções volumétricas em áreas sob manejo florestal na Amazônia Brasileira, bem como verificar a influência das características das espécies e das classes diamétricas na obtenção do volume individual das árvores. Foram analisadas 53 árvores-amostra pertencentes a cinco espécies, separadas em três classes diamétricas. O volume real (VR) foi obtido pelo método de Smalian, com seções fixas de 2 metros ao longo do fuste (VR); o volume geométrico também foi obtido por Smalian, mas com os comprimentos das seções variados ao longo do fuste (VG). Para o volume aproveitável (VA) o volume da perda (VP) foi subtraído do VR. Foi realizada uma ANOVA em esquema fatorial $(5 \times 3 \times 3)$ para verificar o efeito das 5 espécies, das 3 classes diamétricas e 3 práticas de medição de volume (VR, VG e VA) sobre os diferentes volumes obtidos. Houve efeito dos três fatores sob análise, entretanto não houve interações entre essas variáveis. Os volumes obtidos por cubagem de seções com comprimentos diferentes (VG), apresentaram em média volume menor que VR. Apesar de não haver diferença entre as médias de VA e VR, a perda de madeira foi de $6,5 \%$ do volume total. Há uma relação entre comprimentos de seções e volume perdido, conforme a presença de ocos, tortuosidades e rachaduras das toras nas maiores classes diamétricas.
\end{abstract}

Palavras-Chave: Cubagem, Classes de diâmetro, Perdas volumétricas, Manejo florestal comunitário.

\begin{abstract}
The objective of this study was to compare three methods of measuring the volume of individual trees used extensively as a basis for adjusting volumetric functions in areas under forest management in the Brazilian Amazon, and verify the influence of species and diameter classes in obtaining the volume of individual trees. A total of 53 sample trees belonging to five species were analyzed and separated into three diametric classes. The real volume (VR) was obtained using Smalian's method on fixed sections of 2 meters intervals along the stem; the geometric volume (VG) was also obtained by Smalian's method, but with the lengths of the various sections along the stem. Volume loss (VP) was subtracted from the VR to obtain the usable volume (VA). An ANOVA in a factorial design $(5 \times 3 \times 3)$ was performed to verify the effect of 5 species, 3 diameter classes, and 3 volume measurement methods (VR, VG, and VA) on the different volumes obtained. The 3 factors did affect the outcome of the analysis, but there were no interactions found between these variables. The volumes obtained by cubic scaling with different lengths $(\mathrm{VG})$ presented a lower mean volume than VR. Although there was no difference between the means of VA and VR, wood loss was $6.5 \%$ of the total volume. There is a relationship between section length and volume loss, according to the presence of hollows, twists and cracks in the logs in the largest diameter classes.

Keywords: Cubic scaling, Diameter classes, Volumetric losses, Community forest management.
\end{abstract}

\section{INTRODUCTION}

The volume of wood is an important dendrometric measurement for the feasibility analysis of sustainable forest management in the Amazon, as it supplies quantitative information of the forest that informs the decisionmaking process using the forest inventory data in a certain area (BARRETO et al., 2014). This volume depends on a number of indirect factors, such as the measurement method and the adjustment of the equations that estimate the volume, in addition to direct factors, such as the species, size and shape of the stem, and the health of the assessed trees. The assessment of the influence of these factors on the quality of the adjustment is therefore very important to ensure that the equation provides more accurate and precise volumetric estimates, thus assisting in the planning of the activities of a sustainable forest management plan (PMFS).

Three legal norms require the use of a local equation to estimate the volume of standing trees from the Second Annual Operational Plan (POA) of a sustainable forest management unit. The first is Normative Instruction no. 05 of 11/12/2006 (BRASIL, 2008a), which deals with the procedures for the elaboration of a PMFS

FLORESTA, Curitiba, PR, v. 50, n. 3, p. 1457 - 1466, jul/set 2020.

Leão, F. M. et.al.

ISSN eletrônico 1982-4688

DOI: $10.5380 /$ rf.v50 i3. 61393 
in the Amazon. The second is Execution Norm No. 1, of 24/05/2007 (BRASIL, 2008b), which defines technical guidelines to be followed by the PMFS on volumetric issues. Finally, Resolution No. 406 of 02/02/2009 (BRASIL, 2009) establishes the parameters for regulating production by PMFS and the mandatory determination of the volumetric stock after the second year of management through dendrometric measurements. However, these legal instruments do not impose a specific method for adjusting volumetric equations.

In the Brazilian Amazon, volumetric quantification is performed on estimates from linear regression models, where the dependent variable is the real volume (VR), obtained by cubic scaling, and the independent variables are the diameter at $1.30 \mathrm{~m}$ from the ground $(\mathrm{DBH})$ and height of the stem $(\mathrm{H})$, both of which are obtained in the field at the time of the $100 \%$ forest inventory (LANSSANOVA et al., 2018). Cubic scaling is the method commonly used to quantify the VR of trees, consisting of the integration of the existing volume between predefined sections along the stem (NICOLETTI et al., 2015). The use of $2 \mathrm{~m} \times 2 \mathrm{~m}$ meter sections along the tree stem has been suggested in the State of Pará (BARRETO et al., 2014). This practice, however, is time-consuming and costly, because it may require up to five people to carry out the measurements with the required detail and, depending on the size of each tree measurement, the time consumed can exceed 20 minutes (BUZA et al., 2006).

A lower-cost alternative would be to use the geometric volume (VG) for the adjustment of the volumetric equations, which is more commonly used as it requires only two people, taking between five to ten minutes per tree (RIBEIRO et al., 2014; GOMES et al., 2018). This practice is, however, considered less accurate for the determination of the VR (BUZA et al., 2006). The measurements used to determine the VG are recommended by Normative Instruction no. 21, 24/12/2014 (BRASIL, 2014), which deals with the operation and use of the Forest Origin Document (DOF), and by Normative Instruction no. 10 of 8/5/2015 (BRASIL, 2015). These regulations define the rules for the physical organization of timber forest products. The measurements are made in the storage yard and must be recorded for all parts of the sectioned stem and with the exclusion of volumetric losses, such as cracks, imperfections, the presence of a hollow, and damage by pests or diseases. The volumetric losses can be attributed to the characteristics of the forest, such as the phytosanitary condition, the size of the trees, the physical and mechanical attributes of wood of each species, and the processing restrictions according to the specifications of the various timber products marketed (boards, beams, planks, posts, etc.).

To treat the VG as similar to the VR to reduce costs would be to ignore the differences between the measurement practice (method of rigorous cubic scaling versus geometrical method) and the differences in losses, as the final usable volume would be RV minus the volume loss (VP). In addition to volume measurement practices, it is worth mentioning that other factors may impact the volumetric determination, such as the species or group of species and the size of the trees. The diversity of tree species in tropical forests is a problem for the adjustment of volumetric models, since the shape of the species is different, causing an increase in the variance of the real volume data and, consequently, impairing the accuracy of the adjusted volumetric model (AKINDELE; LEMAY, 2006). Regarding the size of the trees, the larger the diameter, the greater the volume, since the correlation between the two variables is strong; however, grouping in diametric classes is a good strategy for setting the volumetric equations (SILVA; SANTANA, 2014).

Given the above, this study aimed at: (i) comparing the 3 practices used to measure volumes (VR, VA, and VG); (ii) verifying the influence of species and diameter classes on the volume of wood obtained by the 3 methods; and (iii) quantifying the volumetric losses after tree felling. The hypothesis tested was that the real volume, as determined by Smalian's cubic scaling method, is statistically similar to the geometric volume and the usable volume. If these volumes are similar, the geometrical method can be used to determine the real volume from the adjustment of volumetric equations for the second Annual Operating Plan, eliminating Smalian's cubic scaling method, which is time-consuming and more expensive.

\section{MATERIAL AND METHODS}

\section{Characterization of the study area}

The study area belongs to the Virola-Jatobá Sustainable Development Project (SDP) III and IV (03 $10^{\circ}$, 06.4' $\mathrm{S}$ and $51^{\circ} 17^{\prime} 55.5^{\prime}$ ' W), Gleba Belo Monte, with an area of 41,640 ha, side road north of $\mathrm{km} 120$ of the Trans-Amazon Highway, Municipality of Anapu, State of Pará (Figure 1). The vegetation is characterized as Dense Ombrophilous Forest. The relief is made up of accentuated plains and mountains, most of which are wavy to strongly wavy. The soils are primarily red and yellow Latosols. The climate is hot and humid, type Am according to the Köppen classification, with annual rainfall being between 1,500 $\mathrm{mm}$ and 2,500 $\mathrm{mm}$, and an average temperature above $27^{\circ} \mathrm{C}$ and below $29.2^{\circ} \mathrm{C}$ (BARRETO et al., 2014).

FLORESTA, Curitiba, PR, v. 50, n. 3, p. 1457 - 1466, jul/set 2020 


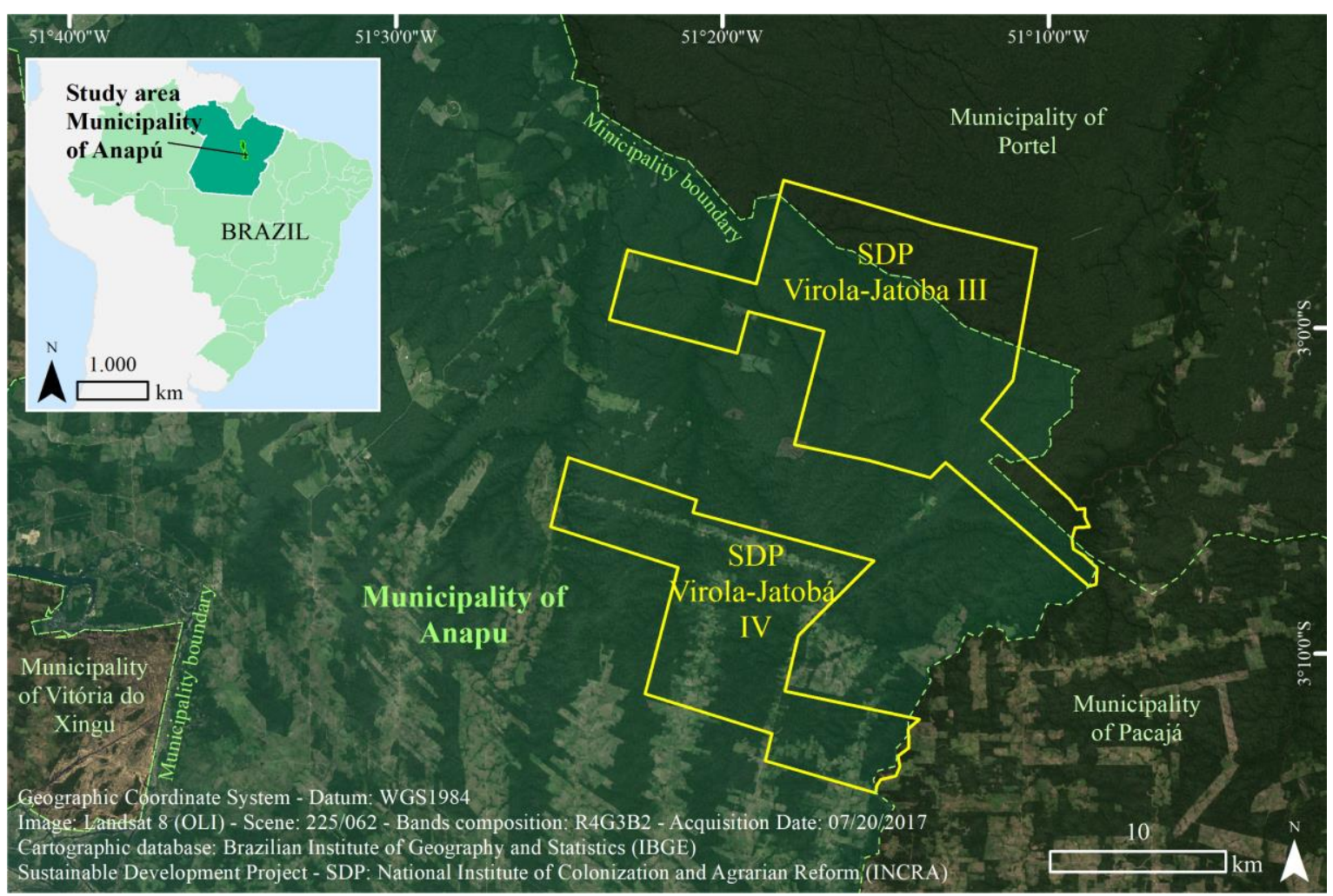

Figure 1. Study area location in PDS III and IV Virola-Jatobá, municipality of Anapu, State of Pará, Brazil.

Figura 1. Localização da área de estudo no PDS III e IV Virola-Jatobá, município de Anapu, Estado do Pará.

The Virola - Jatobá SDP was created in 2002, with the aim of rationally exploiting natural resources and ending illegal deforestation within their lands. In 2006, the community sustainable forest management plan (PMFS) for wood production was implemented in an area of 23,467.73 ha. The objective of the PMFS was to generate socio-environmental and economic development based on participatory management, diversification of economic activities and training of beneficiaries, and compatibility with the productive routine and existing activities, enabling collective construction and the promotion of long-term projects (BARRETO et al., 2014). The annual production units (APU) vary from 500 to 1,000 ha for a 30-year felling cycle, with 30 APUs.

\section{Data Collection}

In $2009,9,603.17 \mathrm{~m}^{3}$ of $\operatorname{logs}$ from 1973 trees belonging to 23 commercial species were harvested. After harvesting, species that contained individuals belonging to different diameter classes were separated for this study. A total of 53 sample trees were used. The samples belonged to five different commercial species, with diameters ranging from 0.60 to $1.20 \mathrm{~m}$. To obtain the real volume (VR), each tree was measured using the Smalian method with the aid of a metric measuring tape, with successive diametric measurements taken every $2 \mathrm{~m}$ along the stem until the last section that could be less than or equal to $2 \mathrm{~m}$ in length:

$$
V R=\sum_{i=1}^{n}\left[\left(g_{i}+g_{i+1}\right) / 2\right] . l
$$

Where $V R$ is the real volume $\left(\mathrm{m}^{3}\right), g_{i+1}$ is the cross-sectional area of the small end $\left(\mathrm{m}^{2}\right), g_{i}$ is the cross-sectional area of the large end $\left(\mathrm{m}^{2}\right), l$ is the length of the section $(\mathrm{m})$, and $n$ is the number of sections.

Volume loss of the same 53 trees was also calculated using the Smalian method immediately after bucking and removal of damaged stem parts that were not used by the sawmills because of the cracks, hollows, and imperfections. The volume loss was subtracted from the VR to obtain the usable volume (VA).

$$
V A=V R-V P
$$

FLORESTA, Curitiba, PR, v. 50, n. 3, p. 1457 - 1466, jul/set 2020.

Leão, F. M. et.al.

ISSN eletrônico 1982-4688

DOI: 10.5380/rf.v50 i3. 61393 
In which: $V A$ is the usable volume $\left(\mathrm{m}^{3}\right), V R$ the real volume, $V P$ the volume loss.

With the aid of a metric tape, the same trees were also measured in the storage yard to obtain the geometric volume (VG), which was calculated by summing up the volumes of each of the bucked logs. To obtain the VG, the section size is the log length itself, which varied because of the bucking process.

$$
V G=\sum_{i=1}^{n}\left[\left(g_{i}+g_{i+1}\right) / 2\right] . l
$$

Where $V G$ is the geometric volume $\left(\mathrm{m}^{3}\right), g_{i+1}$ is the cross-sectional area of the small end $\left(\mathrm{m}^{2}\right), g_{i}$ is the crosssectional area of the large end $\left(\mathrm{m}^{2}\right), l$ is the length of the $\log (\mathrm{m})$, and $n$ is the number of $\operatorname{logs}$.

\section{Data Analysis}

Five species, separated into 3 diameter classes, were analyzed as factors that influence the calculation of the volume using the 3 different methods, creating a randomized factorial design $(5 \times 3 \times 3)$. Note that the 3 diameter classes (class 1: from 0.60 to $0.79 \mathrm{~m}$; class 2: from 0.80 to $0.99 \mathrm{~m}$; and class 3: from 1.00 to $1.20 \mathrm{~m}$ ) were used to guarantee at least two replications in each class (Table 1).

Table 1. Sample size by species and by diametric class studied for the three compared treatments. Tabela 1. Número de amostras (n) por espécie e por classe diamétrica para os três tratamentos.

\begin{tabular}{|c|c|c|c|c|c|}
\hline Species & $\begin{array}{l}\text { Diametric } \\
\text { Class (m) }\end{array}$ & $\begin{array}{c}\text { Number of samples } \\
\text { per treatment }\end{array}$ & $\begin{array}{c}\text { Mean } \\
\text { VR }\left(\mathbf{m}^{3}\right)\end{array}$ & $\begin{array}{c}\text { Mean } \\
\text { VA }\left(\mathbf{m}^{3}\right)\end{array}$ & $\begin{array}{c}\text { Mean } \\
\text { VG }\left(\mathbf{m}^{3}\right)\end{array}$ \\
\hline \multirow{3}{*}{$\begin{array}{l}\text { Syzygiopsis oppositifolia Ducke } \\
\qquad(\mathrm{n}=7)\end{array}$} & 0,60 a 0,79 & 2 & 5,35 & 5,35 & 5,86 \\
\hline & 0,80 a 0,99 & 3 & 9,96 & 9,76 & 10,81 \\
\hline & 1,00 a 1,20 & 2 & 16,89 & 16,01 & 15,67 \\
\hline \multirow{3}{*}{$\begin{array}{l}\text { Manilkara excelsa (Ducke) A.Chev. } \\
\qquad(\mathrm{n}=20)\end{array}$} & 0,60 a 0,79 & 8 & 6,07 & 5,85 & 5,12 \\
\hline & 0,80 a 0,99 & 4 & 8,80 & 8,35 & 7,02 \\
\hline & 1,00 a 1,20 & 8 & 13,97 & 13,65 & 13,18 \\
\hline \multirow{3}{*}{$\begin{array}{l}\text { Manilkara paraensis (A.DC.) A.Chev. } \\
\qquad(\mathrm{n}=7)\end{array}$} & 0,60 a 0,79 & 2 & 6,52 & 5,47 & 4,41 \\
\hline & 0,80 a 0,99 & 3 & 11,02 & 10,13 & 9,51 \\
\hline & 1,00 a 1,20 & 2 & 14,26 & 11,60 & 11,42 \\
\hline \multirow{3}{*}{$\begin{array}{l}\text { Astronium lecointei Ducke } \\
\qquad(\mathrm{n}=8)\end{array}$} & 0,60 a 0,79 & 3 & 7,19 & 6,43 & 5,86 \\
\hline & 0,80 a 0,99 & 2 & 11,63 & 10,78 & 9,95 \\
\hline & 1,00 a 1,20 & 3 & 19,26 & 17,54 & 14,62 \\
\hline \multirow{3}{*}{$\begin{array}{l}\text { Couratari sp. } \\
\quad(\mathrm{n}=11)\end{array}$} & 0,60 a 0,79 & 4 & 6,46 & 6,27 & 6,22 \\
\hline & 0,80 a 0,99 & 4 & 9,89 & 9,46 & 8,62 \\
\hline & 1,00 a 1,20 & 3 & 16,80 & 14,41 & 14,78 \\
\hline Total & & 53 & & & \\
\hline
\end{tabular}

$\mathrm{VR}=$ real volume; $\mathrm{VA}=$ usable volume and $\mathrm{VG}=$ geometric volume.

$\mathrm{VR}=$ volume real; $\mathrm{VA}=$ volume aproveitável e $\mathrm{VG}=$ volume geometrico.

The data of the 53 trees were then transformed by the Box-Cox method for the analysis of variance (ANOVA), using the volumetric means produced by different methods to obtain volume, diameter classes, and species. This step was necessary to identify the lambda value $(\lambda)$ that maximized the maximum likelihood estimator and minimized the residual of the factorial model to be used in the ANOVA. This transformation of the response variable (volume) was for the purpose of meeting the assumptions of homoscedasticity and normality of residuals (AZEVEDO et al., 2015). The means were compared using the Tukey multiple comparison test. All analyses were held with 95\% significance and performed in the R Program 3.4.4 (R Foundation for Statistical Computing, Vienna, AT). 


\section{RESULTS}

After normalizing the data $(\lambda=0.142)$, the factorial analysis indicated differences associated with the method used to calculate volume, the species, and the diameter class, but did not show significant interactions between these factors (Table 2). Thus, the data were reanalyzed without the effect of the interactions between the factors and treating the volume measurement method as blocks. As a result, after the data transformation $(\lambda=$ 0.141), the probability value was increased, now lower than in the previous analysis (Table 3 ).

Table 2. Analysis of variance (ANOVA) in a factorial design $(5 \times 3 \times 3)$ to measure the effect of species, diametric class and methods to obtain trees volume as experimental factors.

Tabela 2. Análise da variância em esquema fatorial $(5 \times 3 \times 3)$ para medir o efeito das espécies, classes diamétrica e práticas de obtenção do volume como fatores experimentais.

\begin{tabular}{cccccc}
\hline SOURCE & DF & SS & MS & F & p \\
\hline Methods & 2 & 0,0171 & 0,0086 & 3,4086 & 0,0365 \\
Species & 4 & 0,0421 & 0,0105 & 4,1872 & 0,0034 \\
Diameter Class & 2 & 0,8525 & 0,4262 & 169,7038 & $<0,0001$ \\
\hline Methods x Species & 8 & 0,0075 & 0,0009 & 0,3737 & 0,9326 \\
Methods x Diameter Class & 4 & 0,0008 & 0,0002 & 0,0848 & 0,9870 \\
Methods x Diameter Class & 8 & 0,0115 & 0,0014 & 0,5732 & 0,7980 \\
Methods x Species x Diameter Class & 16 & 0,0062 & 0,0004 & 0,1555 & 0,9999 \\
\hline Residuals & 114 & 0,2863 & 0,0025 & &
\end{tabular}

$\mathrm{DF}=$ degrees of freedom, $\mathrm{SS}=$ sum of squares, $\mathrm{MS}=$ mean squares, $\mathrm{F}=$ test $\mathrm{F}$ and $\mathrm{p}=$ probability of teste $\mathrm{F}$.

$\mathrm{DF}=$ graus de liberdade, $\mathrm{SS}=$ soma dos quadrados, $\mathrm{MS}=$ quadrados médios, $\mathrm{F}=$ teste $\mathrm{F}$ e $\mathrm{p}=$ probabilidade do teste $\mathrm{F}$.

Table 3. Analysis of variance to measure the effect of species, diametric class and methods to obtain trees volume as experimental factors without interactions effects of the variables.

Tabela 3. Análise de variância para medir o efeito das espécies, classe diamétrica e métodos para obter o volume das árvores como fatores experimentais, sem efeitos de interações das variáveis.

\begin{tabular}{cccccc}
\hline SOURCE & DF & SS & MS & F & p \\
\hline Methods & 2 & 0,0171 & 0,0086 & 4,1100 & 0,0183 \\
Species & 4 & 0,0421 & 0,0105 & 5,0488 & 0,0008 \\
Diameter Class & 2 & 0,8525 & 0,4262 & 204,6235 & $<0,0001$ \\
\hline Residuals & 150 & 0,3125 & 0,0021 & & \\
\hline
\end{tabular}

$\mathrm{DF}=$ degrees of freedom, $\mathrm{SS}=$ sum of squares, $\mathrm{MS}=$ mean squares, $\mathrm{F}=$ test $\mathrm{F}$ and $\mathrm{p}=$ probability of teste $\mathrm{F}$.

$\mathrm{DF}=$ graus de liberdade, $\mathrm{SS}=$ soma dos quadrados, $\mathrm{MS}=$ quadrados médios, $\mathrm{F}=$ teste $\mathrm{F}$ e $\mathrm{p}=$ probabilidade do teste $\mathrm{F}$.

The VR $\left(10.6 \pm 4.79 \mathrm{~m}^{3}\right)$ was statistically higher than the VG $\left(9.27 \pm 4.20 \mathrm{~m}^{3}\right)$. Both VR and VG were statistically equal to the VA $\left(9.86 \pm 4.49 \mathrm{~m}^{3}\right)$ in all species and classes studied (Figure 2). In general, the species A. lecointei presented higher volume $\left(11.56 \pm 5.1 \mathrm{~m}^{3}\right)$ than $M$. excelsa and M. paraensis $(9.32 \pm 4.49$ and $8.99 \pm$ $3.32 \mathrm{~m}^{3}$ respectively), which, in turn, displayed similar volumes to $S$. oppositifolia $\left(10.56 \pm 4.81 \mathrm{~m}^{3}\right)$ and Couratari spp. $\left(9.87 \pm 4.38 \mathrm{~m}^{3}\right)$. There was a significant increase in volume in all species with an increase of diameter class (Class $1=5.90 \pm 1.45$; Class $2=9.30 \pm 2.01$ and Class $3=14.64 \pm 3.77 \mathrm{~m}^{3}$, Figure 2 ).

Although there was no significant difference between the method used to calculate VR and VA, volume losses occurred in $49 \%$ of all individuals measured. In general, the volume loss was $6.5 \%$ of VR. Of the total volume loss, the percentage of hollows (39\%) was higher than cracks (36\%) and imperfections in the stem (25\%), respectively. The volume loss increased with the increase in the diameter class, at $3.7 \%$ in Class $1,5.81 \%$ in Class 2 , and $12 \%$ in Class 3. 


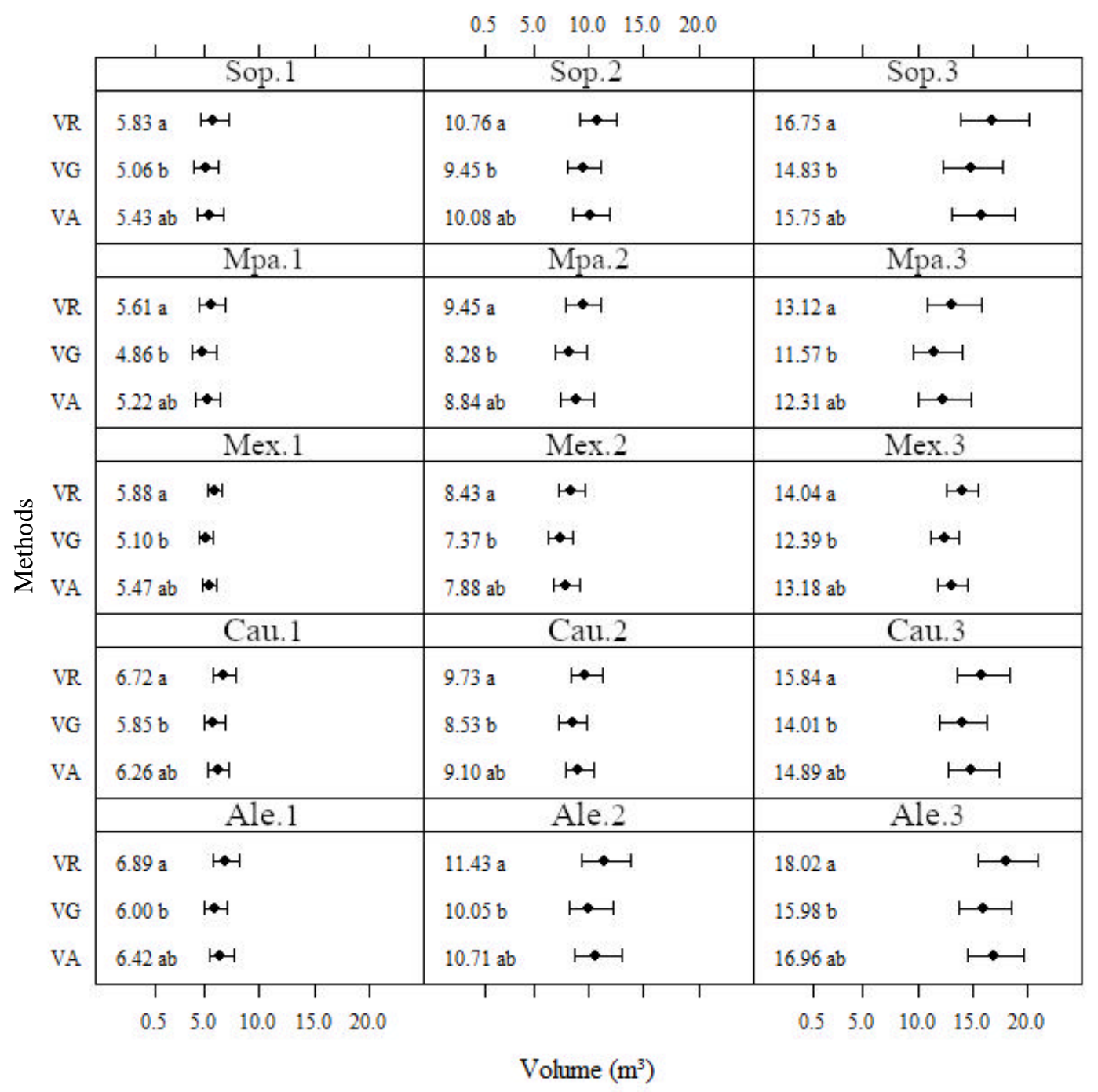

Figure 2. Average volumes and their respective confidence intervals for the different log scaling practices applied to the five species and diameter class analyzed.

Figura 2. Volume médios e seus respectivos intervalos de confiança para as diferentes práticas de cubagem aplicados as cinco espécies e classes de diâmetro analisadas.

The species S. oppositifolia and Couratari spp. displayed the highest percentage of wood volume loss (22.79 and $22.39 \%$, respectively). S. oppositifolia showed losses from hollows, imperfections, and cracks, especially in diameter Class 3 . The species $M$. paraensis also showed losses from hollows, imperfections, and cracks, especially in the diameter Class 2. In contrast, in the species M. excelsa, the volumetric losses were from cracks in the base of the logs, which occurred in all diameter classes studied. The species Couratari spp. showed losses arising from imperfections and cracks unevenly distributed throughout the three diameter classes studied (Table 4). 
Table 4. Average percentage loss in volume by species and diameter class studied.

Tabela 4. Percentual médio de perda em volume por espécie e por classe de diâmetro, estudados.

\begin{tabular}{|c|c|c|c|c|}
\hline Species & $\begin{array}{l}\text { Diametric } \\
\text { Class }\end{array}$ & $\begin{array}{c}\text { Hollow } \\
(\%)\end{array}$ & $\begin{array}{c}\text { Imperfections } \\
(\%)\end{array}$ & $\begin{array}{c}\text { Cracks } \\
(\%)\end{array}$ \\
\hline \multirow{3}{*}{ Syzygiopsis oppositifolia Ducke } & 0,60 a 0,79 & & & \\
\hline & 0,80 a 0,99 & & 2,44 & \\
\hline & 1,00 a 1,20 & 16,07 & 3,57 & 0,71 \\
\hline \multirow{3}{*}{ Manilkara excelsa (Ducke) A.Chev. } & 0,60 a 0,79 & 2,36 & & 1,21 \\
\hline & 0,80 a 0,99 & & & 5,36 \\
\hline & 1,00 a 1,20 & & & 2,41 \\
\hline \multirow{3}{*}{ Manilkara paraensis (A.DC.) A.Chev. } & 0,60 a 0,79 & & & \\
\hline & 0,80 a 0,99 & & 7,44 & 4,76 \\
\hline & 1,00 a 1,20 & 8,33 & & \\
\hline \multirow{3}{*}{ Astronium lecointei Ducke } & 0,60 a 0,79 & 8,09 & 2,5 & \\
\hline & 0,80 a 0,99 & & & \\
\hline & 1,00 a 1,20 & & & 0,59 \\
\hline \multirow{3}{*}{ Couratari spp. } & 0,60 a 0,79 & & 3,16 & \\
\hline & 0,80 a 0,99 & & 3,15 & 0,39 \\
\hline & 1,00 a 1,20 & & 3,79 & 11,9 \\
\hline
\end{tabular}

\section{DISCUSSION}

The different methods used to calculate volume were statistically different, with VR being higher than VG, regardless of species. This result was in contrast to that found by Ribeiro et al. (2014) in the Tapajós National Forest in the state of Pará, where there was no statistically significant difference between the VR and the VG, although the VR was lower than the VG by $2.93 \%$. However, these authors took only whole trees into account, scaled in different sections along the stem, and they did not consider losses as was done in this present study.

The difference between the volumes may be due to the shape of the stem, which can vary in the same hardwood tree species. At the base of the trunk, hardwood trees usually have a convex shape in the longitudinal axis, with an inflection point which varies depending on the species, resembling a truncated neiloid shaped geometric solid. Therefore, the practice of cubic scaling is more reliable because it accounts for the real geometric shape of the stem with greater precision. This feature is very important for the adjustment of volumetric equations, especially those that allow planning of future management within a sustainable forest management unit (DE LEÓN; VALENCIA, 2013).

To ensure greater volumetric accuracy, the distance between the sections at the time of cubic scaling should be the smallest possible (DE LEÓN; URANGA-VALENCIA, 2013). Thus, the calculation of VR, which uses measurements of sections of the stem that are 2 meters apart, is more accurate than the geometrical method, which uses variable sections depending on the size of the stems to be bucked, with an average distance between sections that is greater than 2 meters (BUZA et al., 2006).

The profile of the stem of the species of hardwood trees in the Amazon displays an exponentially decreasing diameter as the length of the log sections increases, up to the largest section, when the diameter may or may not increase (DE LEÓN; URANGA-VALENCIA, 2013). Thus, the greater the length of sections of the trunk during the measuring of the trees, the greater the likelihood that the volume will be overestimated (RIBEIRO et al., 2014). The shape of the trees also changes depending on the removal of the VP, which occurs in both the first log sections and in the last log sections, leaving a more uniform trunk shape and, consequently, differentiating the VR from the VG.

The complexity of the site and the forest physiognomy can affect the shape of the tree stem and the relationship between the diameter and height of the tree stem (AKINDELE; LEMAY, 2006). Volumes may vary 
between and within species, as the population will have individuals of different ages and sizes (AKINDELE; LEMAY, 2006); this variation may explain the differences found within species studied here.

With regard to wood loss during the management process, the volume removed from the stems due to undesirable factors $(6.5 \%)$ did not differ significantly from the VR and the VG. Nevertheless, the losses represented a considerable economic value. Using the marketed log value of US $\$ 100.00 \mathrm{~m}^{-3}$ form Santana et al. (2012), the loss would be approximately US $\$ 3,630.76$ for $36.30 \mathrm{~m}^{3} \log$ loss for the 53 tree samples analyzed, which represents only $2.67 \%$ of the total trees harvested.

The presence of hollows was the main source of loss, and this occurred in nearly all species. The species S. oppositifolia had hollows that were not detected before felling. Hollows or internal rotting of the trunk is a plant disease that occurs internally in the stem in the heartwood and is very difficult to detect with the naked eye (AUER; SANTOS, 2011). One way to detect internal decay is by conducting the hollow test performed at the base of the trees at the time of logging. Although widely used in the Amazon, this test does not indicate the existence of a hollow if it is in the center or at the apex of the tree trunk (AUER; SANTOS, 2011).

Phytopathological studies have shown that this rotting can occur both in both young and mature individuals of any species but occurs more frequently in mature individuals. This may explain the greater volumetric loss found in the largest diametric classes (AUER; SANTOS, 2013). A species may have individuals in different sites possessing different stem quality, depending on the type of soil, rainfall distribution, and wind. These environmental factors can encourage tree infection by a group of microorganisms, mainly fungi, basidiomycetes (white and brown rot) and ascomycetes (soft rot), and some bacteria, which penetrate into the trees through the gaps caused by the death of branches and injuries to the trunk (BOYCE, 1961). These microorganisms act on the cell wall surface in an orderly and sequential manner and are able to degrade both lignin, cellulose, and hemicelluloses (BOYCE, 1961).

The results showed that the intrinsic defects of the tree trunk, such as the irregularities in the constitution and structure of wood caused by twists or the presence of knots, occurred widely and were not unique to a particular species. The tortuosity, that is, the permanent deviations from the straight shape of a tree trunk, can be due to genetics, growth conditions, the slope of the ground, strong winds, and phototropism. These factors can cause changes in the physical and mechanical properties of the wood, which compromises its yield when bucking and dragging logs become necessary. In other words, the greater the incidence and volume of these defects, the greater the wood loss (GARCIA et al., 2005).

Some species that had cracks and fractures caused by the felling of trees, such as M. excelsa, M. paraensis, and Couratari spp, also presented these characteristics in other sites, as mentioned by Amaral et al. (1998). According to Pereira (2012), cracks and fractures are one of the main factors increasing loss in extracted timber, and are mainly caused by the release of growth tensions within the trees, which were in a state of equilibrium when standing. The peripheral zone of the log, under traction, tends to expand and push the cutting face to the outside after cutting, causing cracks in the stem (LATORRACA; ALBUQUERQUE, 2000).

Growth stresses are the result of the action of internal forces acting on the tissues, and play a very important role in providing support, rigidity, and stability to the tree against the force of strong winds and the weight of the crown, and also generates adaptability to topographic gradients (MATA et al., 2015). Growth stresses originate during the maturing of the cambium cells, which tend to contract longitudinally and form a layer of cells under traction and tension (ARCHER, 2013). Longitudinal stresses in the most external parts of the tree stem guarantee a reinforced structure, providing resistance to edaphoclimatic factors (MATA et al., 2015). When cells contract longitudinally, they expand transversely to the medulla of the trees, causing a compression tension in the internal part, which reacts to certain critical loads by sometimes creating cracks in the trunk. In some cases, trees may crack from the impact of falling to the ground (LATORRACA; ALBUQUERQUE, 2000).

The effects of growth tensions are common in low-density wood and are typical for young and fastgrowing trees (LATORRACA; ALBUQUERQUE, 2000). There are techniques for felling trees that lessen the growth tension of the trees, but some species may still present cracks in the stem (AMARAL et al., 1998). The causes of high growth stresses have been directly linked to genetic factors, age, log size, and growth rate of tropical trees (ARCHER, 2013).

FLORESTA, Curitiba, PR, v. 50, n. 3, p. 1457 - 1466, jul/set 2020. 


\section{CONCLUSIONS}

The analyses allowed us to conclude that:

- The geometric volume was lower than the real volume. Therefore, the geometric volume from the measurement of the logs cannot be used to adjust volumetric equations to estimate the volume of standing trees in forest management units in the municipality of Anapu, Pará.

- Morphological characteristics of the tree species and the diametric class did not influence the wood volume obtained by the 3 measurement methods that were evaluated.

- Although there was no difference between the usable volume and the real volume, wood loss occurred in almost half of the trees assessed in this study. Although the loss was small, it may have negative financial implications for the managers.

\section{REFERÊNCIAS}

AKINDELE, S. O.; LEMAY, V. M. Development of tree volume equations for common timber species in the tropical rain forest area of Nigeria. Forest Ecology and Management, Amsterdam, v. 226, n. 3, p. 41-48, 2006.

AMARAL, P.; VERÍSSIMO, A.; BARRETO, P.; VIDAL, E. Floresta para sempre: um manual para a produção de madeira na Amazônia. Ananindeua: Instituto do Homem e Meio Ambiente da Amazonia, 1998, 7 p.

ARCHER, R. R. Growth stresses and strains in trees. Berlim: Springer Science \& Business Media, 3 ed. 2013 , $239 \mathrm{p}$.

AUER, C. G.; SANTOS, A. F. Doenças em eucaliptos destinados à produção de energia na região Sul do Brasil. Pesquisa Florestal Brasileira, v. 31, n. 68, p. 373-379, 2011.

AZEVEDO, A. M.; ANDRADE JÚNIOR, V. C.; FERNANDES, J. S. C. Transformação Box-Cox na homocedasticidade e normalidade uni e multivariada em experimentos de batata-doce. Horticultura Brasileira, Vitória da Conquista, v. 34, n. 1, p. 93-101, 2015.

BARRETO, W. F.; LEÃO, F. M.; MENEZES M.C.; SOUZA D.V. Equação de volume para apoio ao manejo comunitário de empreendimento florestal em Anapu, Pará. Pesquisa Florestal Brasileira, Colombo, v. 34, n. 80, p. 321-329, 2014.

BOYCE, J. S. Forest pathology. New York: McGraw-Hill, 1961, 572p.

BRASIL. Instrução Normativa n. 5 de 11 de dezembro de 2006. Dispõe sobre procedimentos técnicos para elaboração, apresentação, execução e avaliação técnica de Planos de Manejo Florestal Sustentável-PMFSs nas florestas primitivas e suas formas de sucessão na Amazônia Legal, e dá outras providências. Diário Oficial da União, Brasília, DF, treze de dezembro de 2006. Disponível em: <http://www.sbs.org.br/>. Acesso em: 27 fev. 2018. a.

BRASIL. Norma de Execução n. ${ }^{\circ}$ 1, de 24 de abril de 2007. Institui, no âmbito desta Autarquia, as Diretrizes Técnicas para Elaboração dos Planos de Manejo Florestal Sustentável - PMFS de que trata o art. 19 da Lei 4.771, de 15 de setembro de 1965. Diário Oficial da União, Brasília, DF, trinta de abril de 2007. Disponível em: <http://www.ibama.gov.br/>. Acesso em: 27 fev. 2018. b.

BRASIL. Resolução Conama n ${ }^{\circ}$ 406, de 02 de fevereiro de 2009. Estabelece parâmetros técnicos a serem adotados na elaboração, apresentação, avaliação técnica e execução de Plano de Manejo Florestal SustentávelPMFS com fins madeireiros, para florestas nativas e suas formas de sucessão no bioma Amazônia. Diário Oficial da União, Brasília, DF, seis de fevereiro de 2009 Disponível em: <www.mma.gov.br/port/conama/legiabre.cfm?codlegi=597>. Acesso em 19/01/2018.

BRASIL. Instrução Normativa $n^{\circ} 10$ de 08 de maio de 2015. Defini procedimentos de organização física de produtos florestais madeireiros em áreas de exploração florestal e em depósitos e pátios de estocagem de empreendimentos industriais ou comerciais, para fins de controle do rastreamento de produtos oriundos de Planos de Manejo Florestais, Autorizações de Supressão de Vegetação em Empreendimentos sob Licenciamento Ambiental e Autorizações de Uso Alternativo do Solo expedidas pelos órgãos ambientais competentes. Diário Oficial da União, Brasília, DF, doze de maio de 2015. Disponível em: <http://www.ibama.gov.br/sophia/cnia/legislacao/IBAMA/IN0010-08052015.pdf>. Acesso em: 04/04/2018.

FLORESTA, Curitiba, PR, v. 50, n. 3, p. 1457 - 1466, jul/set 2020.

Leão, F. M. et.al.

ISSN eletrônico 1982-4688 
BRASIL. Instrução Normativa n ${ }^{\circ} 21$, de 24 de dezembro de 2014. Dispõe sobre o funcionamento e utilização do Documento de Origem Florestal (DOF). Diário Oficial da União, Brasília, DF, vinte e sete de dezembro de 2014. Disponível em: <www.iap.pr.gov.br/arquivos/File/formularios/IN_21_DE_2014.pdf>. Acesso em 04/04/2018.

BUZA, A. G.; TOURINHO, M. M.; SILVA, J. N. Caracterização da colheita florestal em Cabinda, Angola. Revista de Ciências Agrárias/Amazonian Journal of Agricultural and Environmental Sciences, Belém, v. 45, n. 2, p. 59-78, 2006.

DE LEÓN, G. C.; URANGA-VALENCIA, L. P. Theoretical evaluation of Huber and Smalian methods applied to tree stem classical geometries. Bosque, Valdivia, v. 34, n. 3, p. 311 - 317, 2013.

GARCIA, F. M.; MANFIO, D. R.; SANSÍGOLO, C. A.; MAGALHÃNS, P. A. D. Rendimento no desdobro de toras de Itaúba (Mezilaurus itauba) e Tauari (Couratari guianensis) segundo a classificação da qualidade da tora. Floresta e Ambiente, v. 19, n. 14, p. 468-474, 2012.

GOMES, K. M. A.; SILVA-RIBEIRO, R. R.; GAMA, J. R. V.; ANDRADE, D. F. C. Eficiência na estimativa volumétrica de madeira na Floresta Nacional do Tapajós. Nativa, Sinop, v.6, n.2, p. 170-176, 2018.

LANSSANOVA, L. R.; SILVA, F. A.; SCHONS, C. T.; PERERIRA, A. C. D. S. Comparação entre diferentes métodos para estimativa volumétrica de espécies comerciais da Amazônia. Biofix Scientific Journal, Paraná, v. 1, n. 1, p. 109-115, 2018.

LATORRACA, J. D. F.; ALBUQUERQUE, C. E. C. Efeito do rápido crescimento sobre as propriedades da madeira. Floresta e Ambiente, Rio de Janeiro, v. 7, n. 1, p. 279-291, 2000.

MATA, A. G.; CASTRO, R. V. O.; CORREIA, A. C. G.; REIS, G. G.; REIS, M. D. G. F.; ROSADO, A. M. (2015). Interação árvores e ventos: aspectos ecofisiológicos e silviculturais. Ciência Florestal, Santa Maria, v. 25, n. 2, p. 523-536, 2015.

NICOLETTI, M. F.; BATISTA, J. L. F.; CARVAlHO, S. D. P. C.; CASTRO, T. N.; HESS, A. F. Exatidão de dendrômetros ópticos para determinação do volume de árvores em pé. Ciência Florestal, Santa Maria, v. 25, n. 2, p. 395-404, 2015.

PEREIRA, R. S.; GUIMARÃES, P. B. R.; DEL MENEZZI, C. H. S.; VALE, A. T.; ROBERT, R. C. G. Avaliação da segurança e ocorrência de defeitos na operação de corte semimecanizado de florestas de Eucalipto. Revista Árvore, Viçosa, v. 36, n. 3, p. 511-518, 2012.

RIBEIRO, R. B. S.; GAMA, J. R. V.; MELO, L. O. Seccionamento para cubagem e escolha de equações de volume para a Floresta Nacional do Tapajós. Cerne, Lavras, v. 20, n. 4, p. 605-612, 2014.

SANTANA, A. C.; SANTOS, M. A. S.; SANTANA, Á. L.; YARED, J. A. G. O valor econômico da extração manejada de madeira no baixo Amazonas, estado do Pará. Revista Árvore, Viçosa, v. 36, n. 3, p. 527-536, 2012.

SILVA, E. M.; SANTANA, A. C. Modelos de regressão para estimação do volume de árvores comerciais, em florestas de Paragominas. Revista Ceres, Viçosa, v. 61, n. 5, p. 631-636, 2014. 